\title{
Nitrogen use efficiency as a tool to evaluate the development of ornamental cacti species ${ }^{(1)}$
}

\author{
KARINA GONÇALVES DA SILVA ${ }^{(2) *}$; MAURICIO LAMANO FERREIRA(3); TERESA JOCYS ${ }^{(4)}$; \\ SHOEY KANASHIRO(2), ARMANDO REIS TAVARES ${ }^{(2)}$
}

\begin{abstract}
Nitrogen efficiency, along with associated indexes, is a widely used tool for assessing nutritional status in agricultural species. However, this parameter is not used in studies with ornamental plants, especially epiphytic cacti species. In particular, we know very little about the potential response of ornamental cacti to $\mathrm{N}$ absorption and use. Therefore, this study aimed to evaluate $\mathrm{N}$ use efficiency (NUE), along with its associated parameters, in three species of ornamental cacti under nitrogen nutrition. To accomplish this, Rhipsalis baccifera, Rhipsalis paradoxa and Hatiora salicornioides were fertilized by Hogland and Arnon nutrition solution modified and enriched with urea in the concentrations of $0,33.3$ or $66.6 \mathrm{mM} \mathrm{N}$ during 180 days. At the end of the experiment, efficiency indexes were calculated. Efficiency parameters varied according to species. $R$. baccifera presented the greatest dissimilarity among the species, with highest uptake efficiency (NUpE), but lowest use efficiency (NUtE) and biomass conversion (BCE). R. paradoxa presented high values for NUE, NUtE, BCE and physiological efficiency (NPE) at concentrations of $33.3 \mathrm{mM} \mathrm{N}$, suggesting greater investment in biological processes with lower supply of N. H. salicornioides had the highest averages in most parameters measured. Our results show that these indexes provided important comparative baseline information on nutritional status and investment strategy, thus serving as a suitable analytical tool to increase knowledge about this group of ornamental plants.
\end{abstract}

Keywords: Cactaceae, urea, NUE, plant growth.

\section{RESUMO}

Índices de eficiência do uso de nitrogênio como ferramenta para avaliação do desenvolvimento de espécies de cactos ornamentais

Os índices de eficiência nutricional são ferramentas bastante utilizadas para avaliação de status nutricional e requerimento de nitrogênio (N) em espécies com interesse agrícola. Contudo este parâmetro tem sido pouco utilizado no âmbito dos estudos com plantas ornamentais, sobretudo espécies de cactos epífitos havendo uma lacuna no conhecimento sobre o potencial de respostas que esses índices podem promover sobre as estratégias de absorção e utilização de $\mathrm{N}$ para estas espécies. O objetivo deste estudo foi avaliar a eficiência do uso de N (NUE) e seus demais parâmetros em três espécies de cactos ornamentais sob nutrição nitrogenada. Plantas de Rhipsalis baccifera, Rhipsalis paradoxa e Hatiora salicornioides receberam solução nutritiva de Hougland and Amon modificada e enriquecida com ureia nas concentrações de 0,$0 ; 33,3$ ou $66,6 \mathrm{mM} \mathrm{N}$ durante 180 dias. Ao término do experimento foram calculados os índices de eficiência. Os parâmetros de eficiência variaram de acordo com a espécie, sendo observado que $R$. baccifera apresentou maior dissimilaridade entre as espécies, com a maior eficiência de absorção (NUpE), mas menor eficiência de utilização (NUtE) e conversão em biomassa (BCE). R. paradoxa apresentou alta eficiência de NUE, NUtE, BCE e eficiência fisiológica (NPE), demonstrando maiores valores dessas variáveis nas concentrações de 33,3 mM N, sugerindo maior investimento em processos biológicos com menor fornecimento de $\mathrm{N}$. $H$. salicornioides apresentou as maiores médias na maioria dos parâmetros mensurados. Os índices forneceram importantes informações sobre o status nutricional e estratégia de investimento do N, sendo válida a utilização deste recurso em estudos com plantas ornamentais. Palavras-chave: Cactaceae, ureia, NUE, crescimento vegetal.

\section{INTRODUCTION}

The Brazilian ornamental plant market has seen remarkable growth, as demonstrated by the establishment of an international quality model and development of profitable species of flowers and ornamental plants, thus generating new business opportunities in an emerging industry (JUNQUEIRA and PEETZ, 2008). However, this growth industry is still challenged by the lack of studies on native species with ornamental potential, as well as excessive use of non-native species, and relevant management technologies (FISCHER et al., 2007; OTTMANN et al., 2008; CARDOSO et al., 2013). Thus, world have seen a shift toward modern landscaping which encourages the increased use of native species, highlighting national identity and biological diversity (HEIDEN et al., 2006).

Epiphytic cactus have a main economic importance in world-wide horticultural trade as potted plants; thus a total

\footnotetext{
DOI: http://dx.doi.org/10.14295/oh.v23i4.1063

(1) Received in 19/06/2017 and accepted in 13/11/2017

(2) Instituto de Botânica (IBt), São Paulo-SP, Brazil. *Correspondonding author: karina.gs.bio@gmail.com

(3) Universidade Nove de Julho, Smart and Intelligent Cities Programme, São Paulo-SP, Brazil.

(4) Instituto Biológico, São Paulo-SP, Brazil.

Licensed by CC BY 4.0
} 
of 2.8 million plants of Rhipsalidopsis (also known as Easter cactus) are produced annually in Denmark (Sriskandarajah, et al., 2007). Plants of Hatiora and Rhipsalis are winter bloomers and epiphytic on nature but growth well in soils. Hatiora are branching plants with short branchelets and salmon-colored blossoms; while, Rhipsalis have slender cylindrical branches and beautiful little blossoms and fruits (Wyman, 1997). Epiphytic Cactaceae species are marketed as vase plants that form an ornamental, exotic and dense mass of outstanding stems (SOUZA and LORENZI, 2000; ANDERSON, 2001; MENEGAES et al., 2015). Despite the obvious need, studies focusing on the growth and development of these species are scarce (SPURWAY and THOMAS, 1992; TAVARES et al., 2016). Suitable analytical tools to increase the knowledge of this group are also wanting.

The ability of plants to uptake and use nitrogen $(\mathrm{N})$ determines plant growth capacity and the maintenance of physiological processes (MARSCHNER, 1995; MASCLAUX-DAUBRESSE et al., 2010; ANDERSEN et al., 2017). It is common to use nutritional efficiency indexes to assess agricultural crops. Together, such indexes form a basis for comparing genotypes that have been improved for better utilization of applied nutrients and better management strategies to intensify the yield and/ or vegetative growth (BALIGAR et al., 2001; DOVALE et al., 2012; VIJAYALAKSHMI et al., 2015). However, nutritional efficiency indexes have been neglected in studies on ornamental plants, along with underestimating this tool for evaluating the effects of $\mathrm{N}$ use on the development, nutritional status, and biological processes of ornamental plants.

Nitrogen Use Efficiency (NUE) is intrinsically complex, involving multiple genetic and environmental factors expressed in different parameters, such as nitrogen uptake, use, transport, remobilization, and $\mathrm{N}$ recovery rates, among others. Among these components, Nitrogen Uptake Efficiency (NUpE) and Nitrogen Utilization Efficiency (NUtE) are highlighted owing to their contribution to NUE, as they require that the processes associated with $\mathrm{N}$ uptake, translocation, assimilation, and redistribution function effectively (MOLL et al., 1982; BALIGAR et al., 2001; MASCLAUX-DAUBRESSE et al., 2010; XU et al., 2012). Furthermore, NUE is a key metric in planning the application of $\mathrm{N}$, avoiding its excessive use, and lowering production costs and environmental damage (GOOD et al., 2004).

NUE is traditionally described as the ratio between production and the nutrient applied. In other words, nitrogen use efficiency is defined as nitrogen output in harvested products divided by the nitrogen inputs to the farm or the food system. NUE is based on NUpE defined as the quantity of nutrient uptaken in relation to the unit of root dry matter. NUtE is defined as N uptaken by the plant for conversion to total biomass. Nitrogen Physiological Efficiency (NPE) is the ratio between biological production and the unit of accumulated nutrient. Biomass Conversion Efficiency (BCE) is also a parameter of NUE, and it is defined as the ratio between shoot dry matter and the unit of nutrient in shoot (FAGERIA, 1998; BALIGAR et al., 2001;
XU et al., 2012). Because the correlation between biomass accumulation and growth maintenance is observable at distinct steps of each index, estimating each NUE parameter provides a holistic view of the physiological mechanisms used by plants in relation to the nutrient input.

In this study, we use nutritional efficiency indexes to evaluate ornamental species of epiphytic cacti of the Atlantic Forest, including Rhipsalis baccifera (J.S.Muell.) Stearn, Rhipsalis paradoxa (Salm-Dyck ex Pfeiff.) SalmDyck, and Hatiora salicornioides Britton \& Rose. These plants were fertilized with urea of $\mathrm{N}$ as the nutrient source, aiming to evaluate the use of $\mathrm{N}$ in biological processes. Thus, we asked if (1) nutritional efficiency indexes can be a tool to evaluate the physiological responses of ornamental cactus species and if (2) different species of ornamental cactus have different usage of $\mathrm{N}$.

\section{MATERIAL AND METHODS}

Cuttings of $R$. baccifera, $R$. paradoxa and $H$. salicornioides were cut from plants of the Instituto de Botânica, São Paulo State, Brazil. Cuttings of approximately $5 \mathrm{~cm}$ were planted in polystyrene trays with 200 cells, containing medium textured sand as substrate. After rooting (180 days), seedlings were transplanted into plastic vessels $(0.415 \mathrm{~L})$ with medium textured sand as substrate. Weekly, the plants received $50 \mathrm{~mL}$ of the nutritional solution of Hoagland \& Arnon $n^{\circ} 1$ (1950) modified with urea in concentrations of $0,33.3$ or $66.6 \mathrm{mM} \mathrm{N}$ as described by Tavares et al. (2016).

After 180 days of experimentation, plants were removed from the vase, washed and separated into joint and roots, which were weighed for fresh mass and dried in a forced ventilation oven at $65{ }^{\circ} \mathrm{C}$ until constant weight to obtain dry mass. The analysis of mineral elements was performed in triplicate, and nitrogen was evaluated by the Kjeldahl method.

The following indexes were calculated as proposed by Fageria (1998) and Xu et al. (2012):

Nitrogen Use Efficiency (NUE, $g^{-1}$ ) = Total Plant Dry Mass/Applied Nitrogen (XU et al., 2012).

Nitrogen Uptake Efficiency (NUpE, $\mathrm{g} \mathrm{g}^{-1}$ ) = Nitrogen Uptake/Dry Roots Mass (FAGERIA, 1998).

Nitrogen Utilization Efficiency (NUtE, $\mathrm{g} \mathrm{g}^{-1}$ ) = Total Plant Dry Mass/Nitrogen Content in Whole Plant (ABBADI and GERENDÁS, 2015).

Biomass Conversion Efficiency (BCE, $\mathrm{g} \mathrm{g}^{-1}$ ) $=$ Joint Dry Mass/Nitrogen in Joint (FAGERIA, 1998).

Nitrogen Physiological Efficiency (NPE, g $\mathrm{g}^{-1}$ ) = (Total Plant Dry Mass with Fertilization - Total Plant Dry Mass without Fertilization)/(Accumulated Nitrogen with Fertilization - Nitrogen Accumulated without Fertilization) (FAGERIA, 1998).

Non-metric multidimensional scaling (NMDS) was carried out to identify the behavior of the plants relative to nutritional efficiency indexes. The Euclidean metric distance index was used to analyze two dimensions, considering stress value less than 0.15 . The dissimilarity between the groups was tested from the multivariate technique of similarity analysis (One-Way ANOSIM) 
and was considered significant if $p \leq 0.05$. This statistical analysis was performed in Past, version 2.16. The analysis of variance (ANOVA) followed by the Tukey post-hoc test $(p \leq 0.05)$ in the statistical program Sisvar, version 5.6, was used to evaluate the physiological responses of each species for each measured index.

\section{RESULTS AND DISCUSSION}

As shown in Figure 1, multivariate analysis is diagrammed from the NMDS ordination group, and results show the formation of three homogeneous groups, with a strong overlap of $R$. paradoxa and $H$. salicornioides. This demonstrates high similarity between these species in relation to $\mathrm{N}$ indexes. On the other hand, $R$. baccifera presented the greatest distance in the diagram, suggesting a different use of $\mathrm{N}$ when compared to the other two species. The dissimilarity among the groups, as demonstrated by the diagram, was significant, presenting statistical inference of $p<0.01$, as determined by ANOSIM. These results showed that strategies for use of $\mathrm{N}$ in these Cactaceae species are not dependent on the genus, but rather vary according to the species.

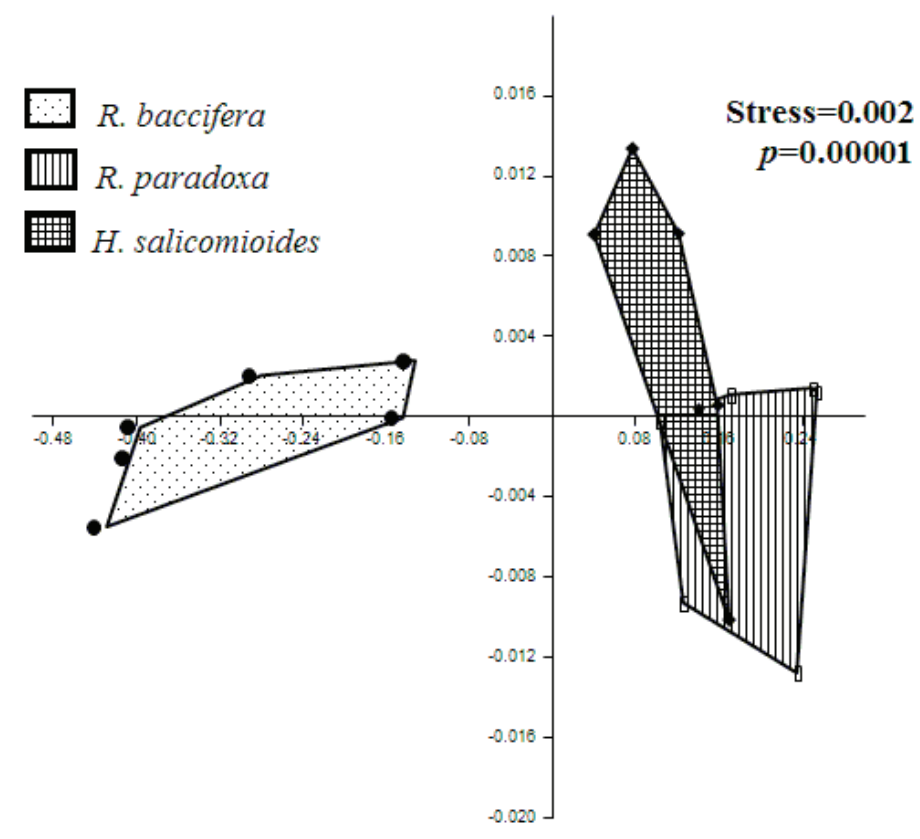

Figure 1. Non-metric multidimensional scaling (NMDS) diagram that represents the ordination of groups based on the Nitrogen Use efficiency (NUE) indexes of the cactus species Rhipsalis baccifera, R. paradoxa and Hatiora salicornioides. The stress value is the distortion between the actual and plotted data in the diagram. Statistical inference of dissimilarity among groups was obtained by Analysis of Similarity (ANOSIM) considering a $p$-value $\leq 0.05$.

When independently compared by ANOVA (Fig. 2), the evaluation of the indexes showed that $R$. baccifera with a concentration of $33.3 \mathrm{mM} \mathrm{N}$ had the lowest NUE with 0.07 $\mathrm{g} \mathrm{g}^{-1}$ (Fig. 2a), while H. salicornioides with a concentration of $66.6 \mathrm{mM} \mathrm{N}$ showed the highest NUE with $0.80 \mathrm{~g} \mathrm{~g}^{-1}$. For these species, increased $\mathrm{N}$ concentration also increased NUE. However, $R$. paradoxa presented the highest NUE with a concentration of $33.3 \mathrm{~mm} \mathrm{~N}$. These results suggest that $R$. paradoxa uses $\mathrm{N}$ more efficiently when compared to the other two species and demonstrate that this species can optimize its biological processes with less N. This behavior is commonly observed in plants with agronomic interest and high NUE, showing higher values when lower nutrient concentrations are applied, essentially because NUE tends to decrease as nutrient levels increase, depending on plant response, owing to relative decrease in plant production with continuous addition of nutrient (MOLL et al., 1982; FAGERIA, 1998; JU et al., 2015).

$R$. baccifera presented the highest NUpE (Fig. 2b) compared to the other two species, being 30 to $40 \%$ higher than that of $R$. paradoxa and $H$. salicornioides, respectively. However, $R$. baccifera also presented the lowest NUtE (Fig. 2c) and BCE (Fig. 2d), differing statistically from the other species. $R$. paradoxa and $H$. salicornioides presented the highest NUtE and BCE at a concentration of $33.3 \mathrm{~mm}$ N. These results suggest a divergence between $\mathrm{N}$ uptake and use for biological processes, such as biomass conversion, demonstrating that the species which uptake large quantities of $\mathrm{N}$ may not be the same as those that make the best use of it. 
Our group studied the epiphytic bromeliads Guzmana lingulata and Vriesea 'harmony' that also demonstrated this tendency (SILVA et al., 2017). More specifically, plants that received $\mathrm{N}$ into tank presented high $\mathrm{NUpE}$, while plants that received $\mathrm{N}$ on roots had the highest NUE, BCE, NUtE and NPE. It is also important to emphasize that $\mathrm{N}$ uptake requires the activation of distinct genes and biochemical mechanisms with correspondingly high energy demands (HIREL et al., 2007; MASCLAUXDAUBRESSE et al., 2010). High capacity to uptake N combined with low $\mathrm{N}$ use for the growth of $R$. baccifera suggests the occurrence of "luxury consumption", a strategy commonly used by slow growth plants that must adapt to environments with low nutritional availability. This phenomenon maximizes nutrient uptake by exceeding the amount of nutrient required for growth. The excess is then stored as reserve (BENZING and RENFROW, 1974; CHAPIN, 1980; VAN WIJK et al., 2003; WINKLER and ZOTZ, 2009). Other studies have reported the occurrence of luxury consumption in Cactaceae species (NOBEL and
DE LA BARREA, 2002; NOBEL and LA BARRERA, 2004; TAVARES et al., 2016).

Physiological efficiency index (NPE) is also an important parameter to assess the responses of nutritional efficiency (XU et al., 2012). H. salicornioides showed the highest NPE being 0.12 and $0.10 \mathrm{~g} \mathrm{~g}^{-1}$ with 33.3 and $66.6 \mathrm{mM} \mathrm{N}$ respectively (Fig. 2e), while $R$. paradoxa showed the lowest NPE at the concentration of 66.6 $\mathrm{mM} \mathrm{N}$ with $0.05 \mathrm{~g} \mathrm{~g}^{-1}$. NPE evaluates the paths in which the uptaken $\mathrm{N}$ is used by the plant, reflecting many physiological processes, such as uptake, nitrate reduction, remobilization, translocation, assimilation and storage (ISFAN, 1990). Higher physiological efficiency reveals the best use of uptaken N (ISFAN, 1993). $R$. paradoxa showed the highest NPE at the lowest $\mathrm{N}$ concentration, supporting the lowest NUpE (Fig. 2b) and NUE optimization (Fig. 2a) in comparison to the other species, as this index demonstrates its ability to use smaller amounts of $\mathrm{N}$ to support physiological processes and growth.
A)

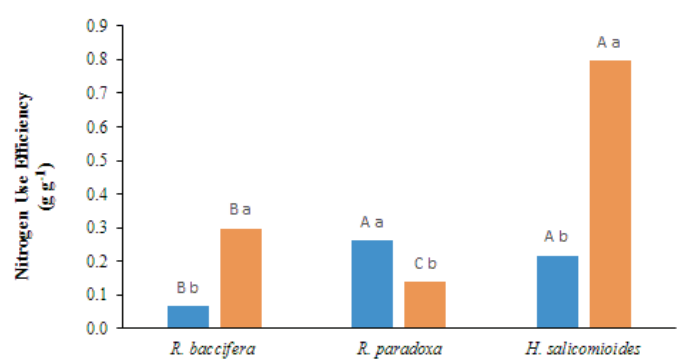

C)

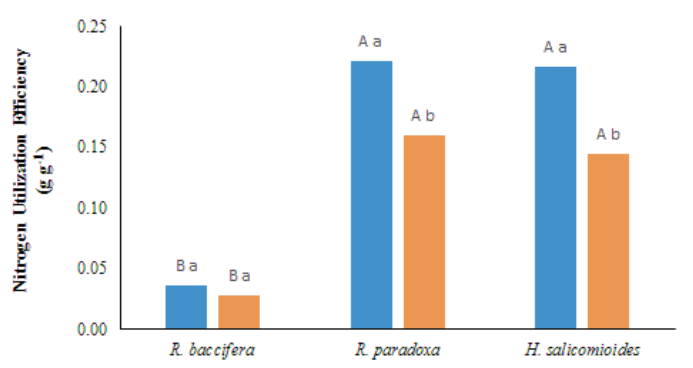

E)

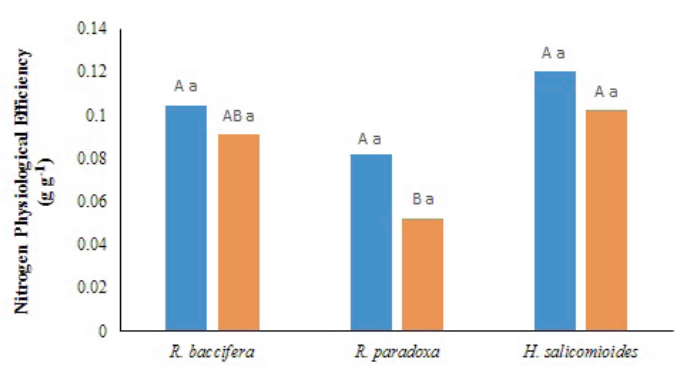

B)

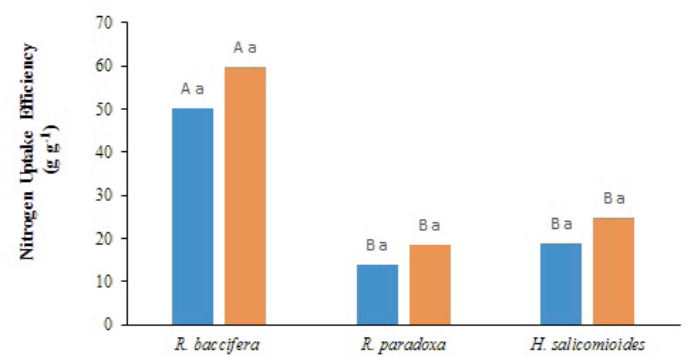

D)

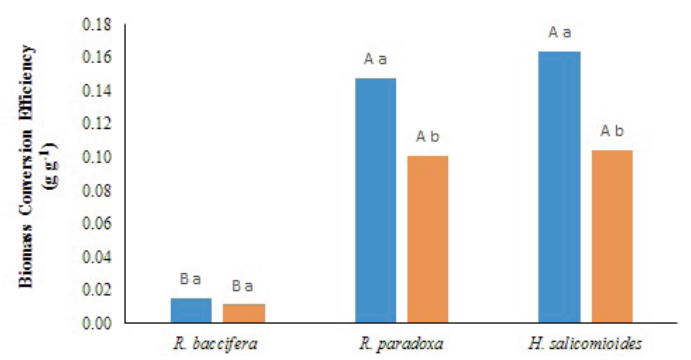

Figure 2. Means of variables: A) Nitrogen Use Efficiency (NUE), B) Nitrogen Uptake efficiency (NUpE), C) Nitrogen Utilization Efficiency (NUtE), D) Biomass Conversion Efficiency (BCE) and E) Nitrogen Physiological Efficiency (NPE) of $R$. baccifera, R. paradoxa and H. salicornioides fertilized with concentration of $33.3 \mathrm{mM} \mathrm{N}$ $(\square)$ and $66.6 \mathrm{mM} \mathrm{N}(\square)$. Uppercase letters represent the comparison among species, and lowercase letters represent the comparison between $\mathrm{N}$ concentrations with the Tukey test $(p \leq 0.05)$. 
The index values of the studied cacti are low when compared to nutritional efficiency values of agricultural crops, such as maize, rice or soybeans (BERENDSE and AERTS, 1987; GOOD et al., 2004; KANT et al., 2011). $R$. baccifera, $R$. paradoxa and $H$. salicornioides are slowgrowing small plants, a fact which justifies the low absolute values observed by the indexes of nutritional efficiency in this study, as calculations are based on the quantity of biomass production. However, similar to agricultural species, nutritional efficiency indexes analyzed for the ornamental cactus species in this study provided important information on the dynamics of $\mathrm{N}$ use by these cacti.

\section{CONCLUSIONS}

The nutritional efficiency indexes provided important information about the nutrition of ornamental cactus. Nutritional differences became apparent by using different indexes, and we observed that different species of ornamental cactus present distinct strategies to uptake and use N. Understanding such strategies is relevant to the cultivation of these plants and selecting native species for horticultural purposes. For example, R. baccifera showed a higher ability to uptake $\mathrm{N}$, but a lower biological utilization of $\mathrm{N}$, while $R$. paradoxa and $H$. salicornioides showed similar responses in relation to the use of $\mathrm{N}$. Thus, we have validated nutritional efficiency indexes as a tool to evaluate the development of ornamental species, providing relevant information to establish an appropriate fertilization management plan for each species, as well as understand the biological aspects of ornamental plants.

\section{ACKNOWLEDGEMENTS}

ART thanks CNPq(306140/2012-8) for the productivity grant.

\section{AUTHORS CONTRIBUTIONS}

KGS: conception and design of the research, obtaining data, analyze and interpretation of data, statistical analysis, write and critically analyses of manuscript. MLF: analyze and interpretation of data, statistical analysis, write and critically analyses of manuscript. TJ: analyze and interpretation of data, statistical analysis, write and critically analyses of manuscript. SK: analyze and interpretation of data, statistical analysis, write and critically analyses of manuscript. ARS: conception and design of the research, obtaining data, analyze and interpretation of data, statistical analysis, write and critically analyses of manuscript and financial and obtaining funding.

\section{REFERENCES}

ABBADI, J.; GERENDÁS, J. Phosphorus use efficiency of safflower (Carthamus tinctorius L.) and sunflower (Helianthus annuus L.). Journal of Plant Nutrition, v.38, n.7, p.1121-1142, 2015). DOI: <http://dx.doi. org/10.1080/01904167.2014>
ANDERSEN, K.M.; MAYOR, J.R.; TURNER, B.L. Plasticity in nitrogen uptake among plant species with contrasting nutrient acquisition strategies in a tropical forest. Ecology, v.98, n.5, p.1388-1398, 2017. DOI: <http:// dx.doi.org/10.1002/ecy.1793>

ANDERSON, E.A. The Cactus Family. Portand: Timber Press, 2001. 776p.

BALIGAR, V.C.; FAGERIA, N.K.; HE, Z.L. Nutrient use efficiency in plants. Communications in Soil Science and Plant Analysis, v.32, n.7-8, p.921-950, 2001. DOI: <http:// dx.doi.org/10.1081/CSS-100104098>

BAUER, D. Sinopse taxonômica de Cactaceae epífitas no Rio Grande do Sul, Brasil. Acta Botanica Brasilica, v.20, n.1, p.225-239, 2006. DOI: <http://dx.doi.org/http://dx.doi. org/10.1590/S0102-33062006000100021>

BENZING, D.H., RENFROW, A. The mineral nutrition of Bromeliaceae. Botanical Gazette, v.135, n.4, p.281-288, 1974. DOI: < https://doi.org/10.1086/336762>

BERENDSE, F.; AERTS, R. Nitrogen-use-efficiency: a biologically meaningful definition? Functional Ecology, v.1, n.3, p.293-296, 1987.

CARDOSO, J.C. Melhoramento de espécies ornamentais como estratégia para o desenvolvimento e autossuficiência do setor. Horticultura Brasileira, v.31, n.1, p.1, 2013. DOI: $<$ http://dx.doi.org/10.1590/S0102-05362013000100028>

CHAPIN, F.S. The mineral nutrition of wild plants. Annual Review of Ecology and Systematics, v.11, n.1, p.233260, 1980. DOI: <http://dx.doi.org/10.1146/annurev. es.11.110180.001313>

DOVALE, J.C., FRITSCHENETO, R., BERMUDEZ, F., MIRANDA, G.V. Efeitos gênicos de caracteres associados à eficiência no uso de nitrogênio em milho. Pesquisa Agropecuária Brasileira, v.47, n.3, p.385-392, 2012. DOI: <http://dx.doi.org/10.1590/S0100-204X2012000300010>

FAGERIA, N.K. Otimização da eficiência nutricional na produção das culturas. Revista Brasileira de Engenharia Agrícola Ambiental, v.2, n.1, p.6-16, 1998. DOI: <http:// dx.doi.org/10.1590/1807-1929/agriambi.v02n01p6-16>

FISCHER， S.Z.; STUMPF， E.R.T.; HEIDEN， G.; BARBIERI, R.L.; WASUM, R.A. Plantas da flora brasileira no mercado internacional de floricultura. Revista Brasileira de Biociências, v.5, n.1, p.510-512, 2007.

GOOD, A.G.; SHRAWAT, A.K.; MUENCH, D.G. Can less yield more? Is reducing nutrient input into the environment compatible with maintaining crop production? Trends in plant Science, v.9, n.12, p.597-605, 2004. DOI: <http:// dx.doi.org/10.1016/j.tplants.2004.10.008> 
HEIDEN, G.; BARBIERI, R.L.; STUMPF, E.R.T. Considerações sobre o uso de plantas ornamentais nativas. Ornamental Horticulture, v.12, n.1, p.2-7, 2006.

HIREL, B.; LE GOUIS, J.; NEY, B.; GALLAIS, A. The challenge of improving nitrogen use efficiency in crop plants: towards a more central role for genetic variability and quantitative genetics within integrated approaches. Journal of Experimental Botany, v.58, n.9, p.2369-2387, 2007. DOI: < https://doi.org/10.1093/jxb/ erm097>

HOAGLAND, D.R.; ARNON, D.I. The water-culture method for growing plants without soil. Circular 347. Berkeley: California Agricultural Experiment Station, 1950.32p.

ISFAN, D. Genotypic variability for physiological efficiency index of nitrogen in oats. Plant and Soil, v.154, n.1, p.53-59, 1993. DOI: < http://dx.doi.org/10.1007/ BF00011071>

ISFAN, D. Nitrogen physiological efficiency index in some selected spring barley cultivars. Journal of Plant Nutrition, v.13, n.8, p.907-914, 1990. DOI: <http://dx.doi. org/10.1080/01904169009364125>

JU, C.; BURESH, R.J.; WANG, Z.; ZHANG, H.; LIU, L.; YANG, J.; ZHANG, J. Root and shoot traits for rice varieties with higher grain yield and higher nitrogen use efficiency at lower nitrogen rates application. Field Crops Research, v.175, p.47-55, 2015. DOI: <http://dx.doi. org/10.1016/j.fcr.2015.02.007>

JUNQUEIRA, A.H.; PEETZ, M.S. Mercado interno para os produtos da floricultura brasileira: características, tendências e importância socioeconômica recente. Revista Brasileira de Horticultura Ornamental, v.14, p.37-52, 2008.

KANT, S.; BI, Y.M.; ROTHSTEIN, S.J. Understanding plant response to nitrogen limitation for the improvement of crop nitrogen use efficiency. Journal of Experimental Botany, v.62, n.4, p.1499-1509, 2011. DOI: <http://dx.doi. org/10.1093/jxb/erq297>

MARSCHNER, H. Mineral nutrition of higher plants. San Diego: Academic Press, 1995. 889p.

MASCLAUX-DAUBRESSE， C.; DANIEL-VEDELE, F.; DECHORGNAT, J.; CHARDON, F.; GAUFICHON, L.; SUZUKI, A. Nitrogen uptake, assimilation and remobilization in plants: challenges for sustainable and productive agriculture. Annals of Botany, v.105, n.7, p.1141-1157, 2010. DOI: <http://dx.doi.org/10.1093/aob/ mcq028>
MENEGAES, J.F.; BACKES, F.A.A.L.; BELLÉ, R.A.; BACKES, R.L. Diagnosis of the retail flower market of Santa Maria, RS. Ornamental Horticulture, v.21, n.3, p.291-298, 2015. DOI: <http://dx.doi.org/10.1590/0103$8478 \mathrm{cr} 20151611>$

MOLL, R.H.; KAMPRATH, E.J.; JACKSON, W.A. Analysis and interpretation of factors which contribute to efficiency of nitrogen utilization. Agronomy Journal, v.74, n.3, p.562-564, 1982. DOI: <http://dx.doi.org/10.2134/agr onj1982.00021962007400030037x>

NOBEL, P.S.; DE LA BARRERA, E. Nitrogen relations for net $\mathrm{CO}_{2}$ uptake by the cultivated hemiepiphytic cactus, Hylocereus undatus. Scientia Horticulturae, v.96, n.1, p.281-292, 2002. DOI: <http://dx.doi.org/10.1016/s03044238(02)00060-2>

NOBEL, P.S.; LA BARRERA, E. $\mathrm{CO}_{2}$ uptake by the cultivated hemiepiphytic cactus, Hylocereus undatus. Annals of Applied Biology, v.144, n.1, p.1-8, 2004. DOI: <http://dx.doi.org/10.1111/j.1744-7348.2004>

OTTMANN, M.A.; FOGAÇA, L.A.; BORSATTO, R.S.; RIBAS, K.C.Z.; KOEHLERS, H.S.; FONE, N.N. Por que estudar a produção de plantas ornamentais? O caso catarinense. Revista Brasileira de Horticultura Ornamental, v.14, p.85-90, 2008.

SILVA, K.G.; SILVA, E.A.; FERREIRA, M.L.; KANASHIRO, S.; CAMARGO, P.B.; TAVARES, A.R. Gas exchange and chlorophyll $a$ fluorescence parameters of ornamental bromeliads. Ornamental Horticulture, v.23, n.4, p. 400-406, 2017. DOI: <http://dx.doi.org/10.14295/ oh.v23i4.1064>

SOUZA, V.C.; LORENZI, H. 2000. Botânica SistemáticaGuia ilustrado para identificação das famílias Fanerogamas nativas e exóticas do Brasil, baseado em APGII. Nova Odessa: Instituto Plantarum de estudos da Flora. 704p.

SPURWAY, M.I.; THOMAS, M.B. The influence of watering, shading and nitrogen levels on the growth of Schlumbergera x buckleyi. Combined Proceedings International Plant Propagators Society, v.42, p.297303. 1992.

SRISKANDARAJAH, S.; AL-RAMAMNEH, E.A.D.; SEREK, M. Biotechnology of Schlumbergera and Rhipsalidopsis. Floriculture and Ornamental Biotechnology, v.1, n.1, 14-19, 2007.

TAVARES, A.R.; FERREIRA, M.L;; JOCYS, T.; KANASHIRO, S.; SILVA, K.G. Urea concentration on vegetative development and nutrition of Cactaceae epiphytic species. Horticultura Brasileira, v.34, n.3, p.340-345, 2016. DOI: <http://dx.doi.org/10.1590/S010205362016003006> 
TAYLOR, N.; ZAPPI, D. Cacti of Eastern Brazil. Kew: The Royal Botanic Garden, 2004. 498p.

VAN WIJK, M.T.; WILLIAMS, M.; GOUGH, L.; HOBBIE, S. E.; SHAVER, G.R. Luxury consumption of soil nutrients: a possible competitive strategy in above ground and below ground biomass allocation and root morphology for slow growing arctic vegetation? Journal of Ecology, v.91, n.4, p.664-676, 2003. DOI: <http:// dx.doi.org/ 10.1046/j.1365-2745.2003.00788.x>

VIJAYALAKSHMI, P.; VISHNUKIRAN, T.; KUMARI, B.R.; SRIKANTH, B.; RAO, I.S.; SWAMY, K.N.; SUBRAHMANYAM, D. Biochemical and physiological characterization for nitrogen use efficiency in aromatic rice genotypes. Field Crops Research, v.179, p.132-143, 2015. DOI: <http://dx.doi.org/10.1016/j.fcr.2015.04.012>
WINKLER, U.; ZOTZ, G. Highly efficient uptake of phosphorus in epiphytic bromeliads. Annals of Botany, v.103, n.3, p.477-484, 2009. DOI: <http://dx.doi. org/10.1093/aob/mcn231>

WYMAN, D. Wyman's gardening encyclopedia. Scribner, New York, 1997. 1221p.

XU, G.; FAN, X.; MILLER, A.J. Plant nitrogen assimilation and use efficiency. Annual Review of Plant Biology, v.63, p.153-182, 2012. DOI: <http://dx.doi.org/10.1146/ annurev-arplant-042811-105532> 